\title{
Policy Factors Affecting Broadband Development in Poland
}

\author{
Anders Henten and Iwona Windekilde \\ Center for Communication, Media and Information Technologies, \\ Aalborg University, Denmark \\ E-mail: henten@cmi.aau.dk; iwona@cmi.aau.dk
}

Received: August 2013; Accepted: September 2013

\begin{abstract}
Poland joined the EU in 2004 and still has one of the Europe's least developed information societies. Broadband penetration in Poland is still amongst the lowest in the EU and significantly below the EU average.

Considering the present state of information technology, the key challenge for Poland is to reduce the gap between Poland and other EU Member Countries in the area of the development and implementation of information and communication technologies. However, Poland's accession to the European Union and the implementation of EU regulation mechanisms accelerate the integration of Poland's telecommunications market with the European market. The market reflects all the global trends, a gradually growing significance of mobile telecommunications services, broadband Internet access, construction of offers directed towards clients' needs, and a strong trend towards market consolidation, which will gradually change the previous balance of power.

The specific problem of the Polish market is its very poor infrastructure development and the lack of competitors on the fixed market. This translates into limited access to services for end users particularly in the rural areas. A much lower level of telecommunications network development in Poland than other countries in the European Union is the reason that the circumstances and also the effects of the implementation of some solutions of the EU regulation model are different in Poland than in the most developed EU countries.
\end{abstract}

Journal of NBICT, Vol. 1, 73-108.

doi: 10.13052/NBICT.2015.004

(C) 2015 River Publishers. All rights reserved. 
The aim of the paper is to examine and discuss broadband access development in Poland and the policy factors influencing this development as well as to examine national strategies used to stimulate service and infrastructure competition in Poland. There are, indeed, many other factors affecting broadband development such as the income level/distribution in the country and the infrastructural point of departure. The paper, therefore, analyses the implications of the policy initiatives in light of these basic conditions and the broader context of factors influencing broadband development.

In the paper, different kinds of policy initiatives are examined - with the 'lightest' forms of intervention first and the 'strongest' at the end. Furthermore, empirical evidence on the developments in access technologies and the policy initiatives taken by the Polish government are presented. Finally, there is a conclusion regarding the importance of the different types of public policy initiatives for broadband take-up in Poland.

\section{Introduction}

The aim of the paper is to examine and discuss broadband access development in Poland and the policy factors influencing this development. There is emphasis on the specific factors affecting broadband development in Poland. However, the conclusions are seen in the broader perspective of policy factors affecting broadband development in general - which constitute the basis for analysing the specificity of the Polish context.

Poland has a national broadband strategy, and the focus in the paper is on the implications of this policy strategy. There are, indeed, many other factors affecting broadband development such as the income level/distribution in the country and the infrastructural point of departure. The present paper, therefore, analyses the implications of the policy initiatives in light of these basic conditions and the broader context of factors influencing broadband development.

\section{Analytical Framework}

In recent years, and especially in the middle of the past decade, a number of publications have been issued discussing the factors - including political factors - affecting broadband development. The point of departure is the observation that the penetration of broadband varies to a great extent even between countries with similar GDP per capita. Examples of such publications are 'Global broadband battles - Why the US and Europe lag while Asia leads', 
edited by Martin Fransman (2006) and papers on 'Penetration of broadband services - The role of policies' by Morten Falch (2007) and 'The role of government in broadband access' by Arnold Picot and Christian Wernick (2007). Other examples of contributions in the field are 'Effects of national policy on the diffusion of broadband in the OECD countries' by Johannes M. Bauer et al (2004) and 'Efficiency of public policy promotions policies in the diffusion of broadband networks - An Exploratory analysis' by Grancesc Miralles (2006).

In line with the approaches in such contributions, there are two basic aspects of broadband developments that have to be taken into consideration: the network aspect and the services (including content) aspect. It is often claimed that what users demand are services and not the networks for the delivery of services. This is, however, either a truism or a truth with modifications. Often, users will demand higher access speeds without demanding specific services requiring higher access speeds, however anticipating a future need. Once users have acquired higher access speeds, services and content requiring such higher speeds are developed and find their way to the market. There is thus interplay between the development of services and networks as illustrated in Figure 1. Broadband policies can affect some or all four aspects (demand for services, supply of services, demand for networks, and supply of networks) and specific national policies will differ with respect to the emphasis on the four different aspects.

Demand for services

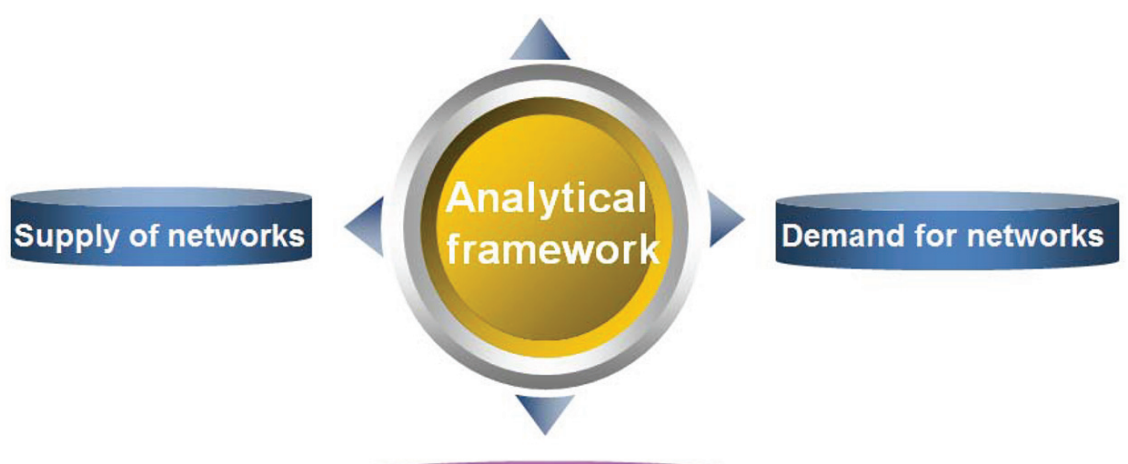

Supply for services

Figure 1 Demand and supply of networks and services 
Policy initiatives affect the four different aspects in various ways. In the paper, different kinds of policy initiatives are examined - encompassing the 'lightest' forms of intervention first and the 'strongest' at the end:

- Strengthening and harmonisation of the internal uses of ICT (information and communication technology) networks and services in public institutions.

- Developing public communication networks and services relating to citizens and business enterprises - with influences on the take-up and forms of communication used in the society at large.

- Facilitation of the development of communication networks and services. This may include increasing transparency in the markets by way of public information on qualities and prices of communication networks and services, and it may include the setting up by public agencies of forums for discussions on, e.g., interconnection and frequency issues among the competing operators and the public authorities.

- Regulation proper, setting the 'rules of the game' in the markets, and the enforcement of such rules.

- Support for the demand for communication networks and services, which may be based on either the direct demand from public institutions or support for the demand from private citizens and business enterprises. Included in this category can also be mentioned education initiatives enhancing the competences of people in using ICT networks and services.

- Support for the supply of ICT networks and services, which may involve public funds going into network and service deployment, but which may also be of a more indirect character involving public research and development and public education of people whose labour power will be used in ICT business enterprises.

The list illustrates different modes of public policy intervention and market construction (Henten, Falch, 2007). Other kinds of sub-divisions of policy initiatives can be made. An example is Rob Frieden, who in a paper in Telecommunications Policy from 2005 classifies policy initiatives in three main groups: regulatory initiatives, supply side stimulation, and demand side stimulation (Frieden, 2005). A similar classification was used by Anders Henten in a paper from 2001 entitled 'Optimal framework conditions for ICT development' (Henten, 2001). The list of initiatives examined in the present paper is an elaboration on these three basic types of public intervention. Not only are they up for consideration for possible policy initiatives, they are actually used in most countries. However, the mix of policy initiatives and the 
more specific features of the different kinds of initiatives vary. The challenge for countries lies in the best mix of initiatives in their specific contexts. In the case of Poland, the paper examines the actual initiatives taken in relation to the possible policy options listed.

The two first mentioned points are related to e-government initiatives. They concern the use of ICTs internally in public organisations and public sector organisations' communications with citizens and companies. The activities of public administrations in these fields will indirectly lead to the promotion of the use of ICTs on a broader scale in society.

The two following points are connected to the ICT sectors themselves facilitating their modes of functioning and setting and enforcing the regulatory frameworks. Facilitation as well as regulation can have decisive influences on the industrial development. The whole liberalisation process in telecommunications has definitely had a great influence on the development of this sector.

The two last points, support for demand and supply, are often connected with the term industrial policy. Public support for the demand side can be important for industrial development and is seen as more acceptable than support for the supply side. State initiatives in the field can be of different kinds. State procurement in itself is important, as state organisations often are large customer, and as goods and services based on new technologies can be helped to grow in the market by means of initial fostering. But the state can also help specific sectors by promoting private demand, either by creating a fertile environment for industries, which are large users of specific goods or services, or by helping residential demand.

Support for the supply side includes direct economic support, which has often been seen as the essence of traditional industrial policies. This kind of industrial policy measure has lost importance in the EU and elsewhere during the past couple of decades. It is, generally, neither favoured by the individual member states nor the EU as such, as it is seen as distorting to the competitive environment. However, when dealing with less profitable, e.g. rural, areas, there is support for public funding at the EU level as well as the national level. In a Communication from the European Commission, public funding including funding from the EU Structural Funds and the Rural Development Fund is explained and recommended as one of the 'available instruments'(Commission of the European Communities: 'Bridging the broadband gap', 2006).

There are, however, other kinds of policies supporting the supply side of industries which are not only generally accepted but also considered as 
strongly recommendable, as they are more certain to contribute to technology developments. This applies to R \& D initiatives as well as educational initiatives, which in both cases can be of a general nature, not discriminating between different industrial areas, but can also favour specific sectors of the economy, which most often has been the case with publicly funded R \& D. It also applies to initiatives promoting industrial development by way of supporting the development of innovative milieus, for instance in the form of science parks, intelligent cities, etc.

In the following, there is first a section with empirical evidence on the broadband related developments in Poland. The paper, thereafter, examines the policy initiatives taken by Polish governments in the last few years. Finally, there is a conclusion regarding the importance of the different types of public policy initiatives.

\section{Developments in Access Technologies in Poland}

The major technologies to provide a broadband Internet access in Poland are: xDSL, DOCSIS/EURODOCSIS, 2G/3G, LAN/WLAN, FTTx.

\subsection{Digital Subscriber Line (xDSL)}

The $\mathrm{xDSL}$ technology is the most popular technology in Poland followed by CATV networks. Other technologies, with a large share in the total number of lines used to provide broadband Internet access services, are mobile Internet and LAN/WLAN Ethernet.

The xDSL technology has 44\% market share (January 2013). Such a large share is mostly a result of constructing the incumbent's networks in copper technology. Therefore the largest provider of broadband services provided via xDSL modems is TP S.A. ${ }^{1}$ (incumbent).

It is important to mention that total DSL coverage is relatively low in Poland, which partly explains the low fixed broadband penetration (18.8\%) compare to the EU average of $28.8 \%$.

Poland occupies the second last position among EU countries from the point of view of fixed broadband penetration rate. Even though the penetration gap to the average of EU countries is significantly reduced compared to few years before, Poland continues to rank among the last, surpassing only Romania (16.6\%).

\footnotetext{
${ }^{1}$ TP S.A. (Telekomunikacja Polska) was renamed Orange Polska on April 2012, in line with France Télécom's international telecommunications branding.
} 


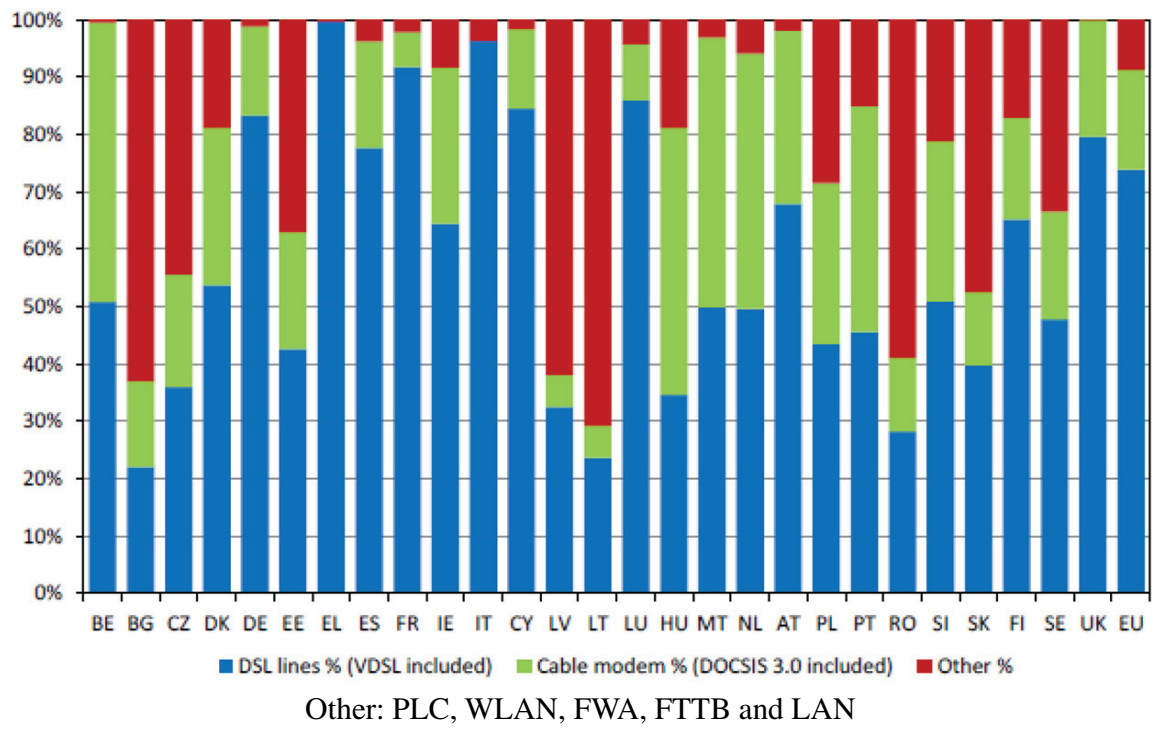

Figure 2 Fixed broadband lines - technology market shares, January 2013

Source: Digital agenda scoreboard 2013, ec, brussels, 12.06.2013

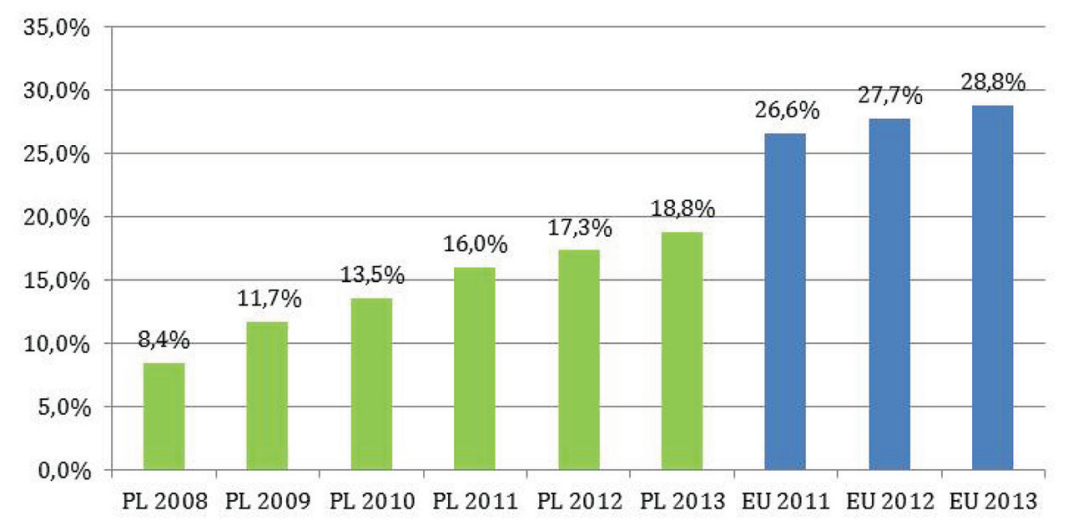

Figure 3 Fixed broadband penetration, Poland 2008-2013, EU 2011-2013

Source: Digital agenda scoreboard 2013, EC, brussels, 12.06.2013, digital agenda scoreboard 2012, fast and ultra-fast internet access; digital agenda scoreboard 2011, electronic communications market indicators; progress report on the single european electronic communications market (15th report).

Despite the fact Poland is in the group of countries with the lowest penetration level in the EU, its penetration growth is slightly above the average EU penetration growth rate, mainly because of incumbent TP S.A. investment 


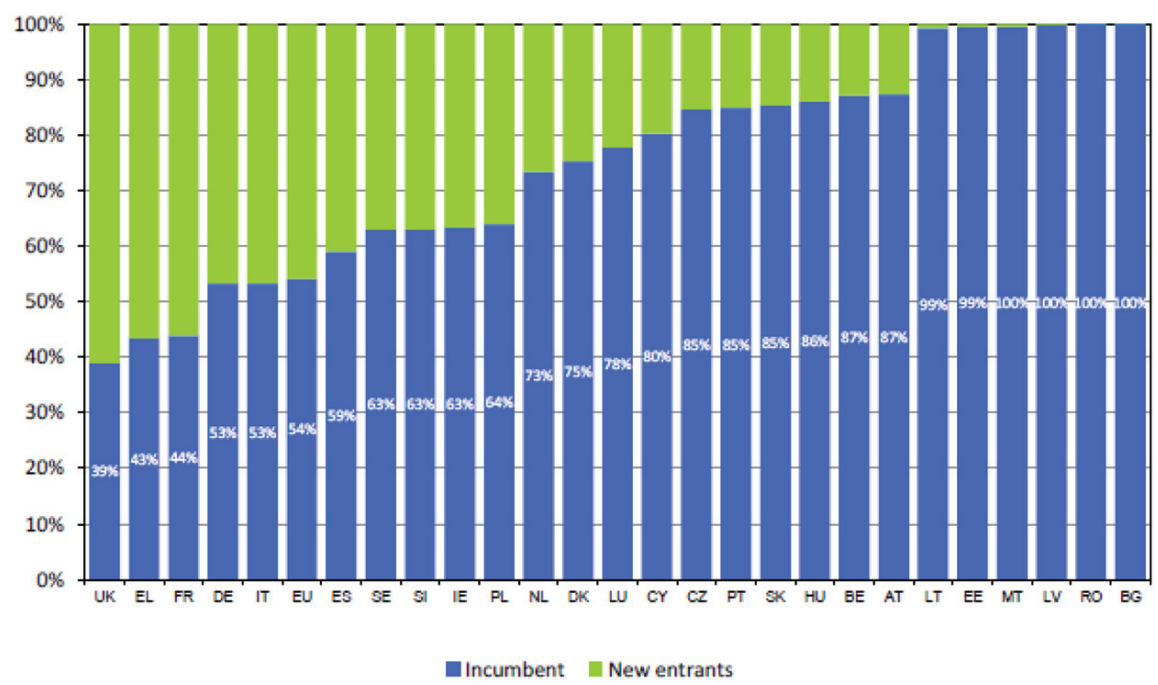

Figure 4 DSL lines - operator market shares, January 2013

Source: Digital agenda scoreboard 2013, EC, brussels, 12.06.2013

commitments associated with the development of broadband infrastructure. TP S.A. is obligated to build or modernize at least 1.2 million broadband lines.

In the DSL market, TP S.A. has still an overwhelming majority market share of $64 \%^{2}$. The remaining $36 \%$ of the lines used to provide retail Internet access service based on DSL technology in Poland are the lines of alternative operators. (January 2013).

In line with the general trend of fixed to mobile substitution, the TP S.A. market share of fixed broadband access lines continues to decrease to the benefit of new entrants.

Unfortunately, Poland is among three Member States (Estonia, Poland and Slovenia), where more than $15 \%$ of lines continues to be at speeds in the lowest range of 144 Kbps-2MBps (Poland 18\% in January 2013). Moreover, the deployment of high-capacity broadband line is still limited, with about $35 \%$ fixed broadband lines providing more than $10 \mathrm{Mbps}$. Even though broadband connections are getting faster, ultrafast Internet access is still rare in Poland only $1.3 \%$ of fixed broadband connections are above $100 \mathrm{Mbps} .^{3}$ This indicates that Poland is still far away from achieving the high-speed targets of the Digital

\footnotetext{
${ }^{2}$ Digital Agenda Scoreboard 2013, EC, Brussels, 12.06.2013.

${ }^{3}$ Poland: Broadband markets, Digital Agenda Scoreboard 2013, EC, Brussels, 2013.
} 
Agenda for Europe, which are 50\% coverage of broadband access technologies of at least $100 \mathrm{Mbps}$ in 2020.

\subsection{CATV - The Data Over Cable Service Interface Specification (DOCSIS)}

The second largest technology with regard to the number of fixed terminators used by operators for the provision of broadband data transmission services is the technology of the DOCSIS standard. It is commonly used by operators of cable television networks. At the beginning of 2013, cable broadband lines' share in fixed broadband amounted to $28 \%$ and it was higher than the EU average of $10 \%$. Popularity of cable TV in Poland is caused most of all by the more attractive offer (higher bandwidth offer) at a comparable retail price to PSTN network operators.

It should be remembered that Internet access services via cable television is still used mainly by inhabitants of larger cities. Lack of common access to the Internet in less urbanized areas is still a serious problem on the Polish Internet access market. Report published by European Commission (EU service based on IDATE) has revealed that most of the unconnected households in rural areas are in Poland (37\%), followed by Germany (9\%) and Italy $(6 \%)$.

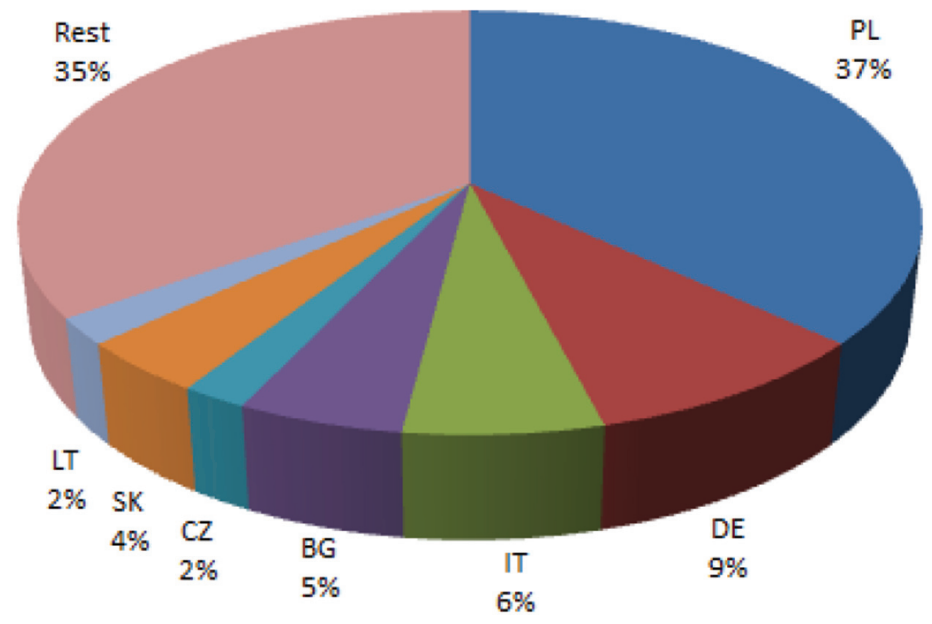

Figure 5 None covered rural households in the EU

Source: Fast and ultra-fast internet access. EC services based on IDATE 


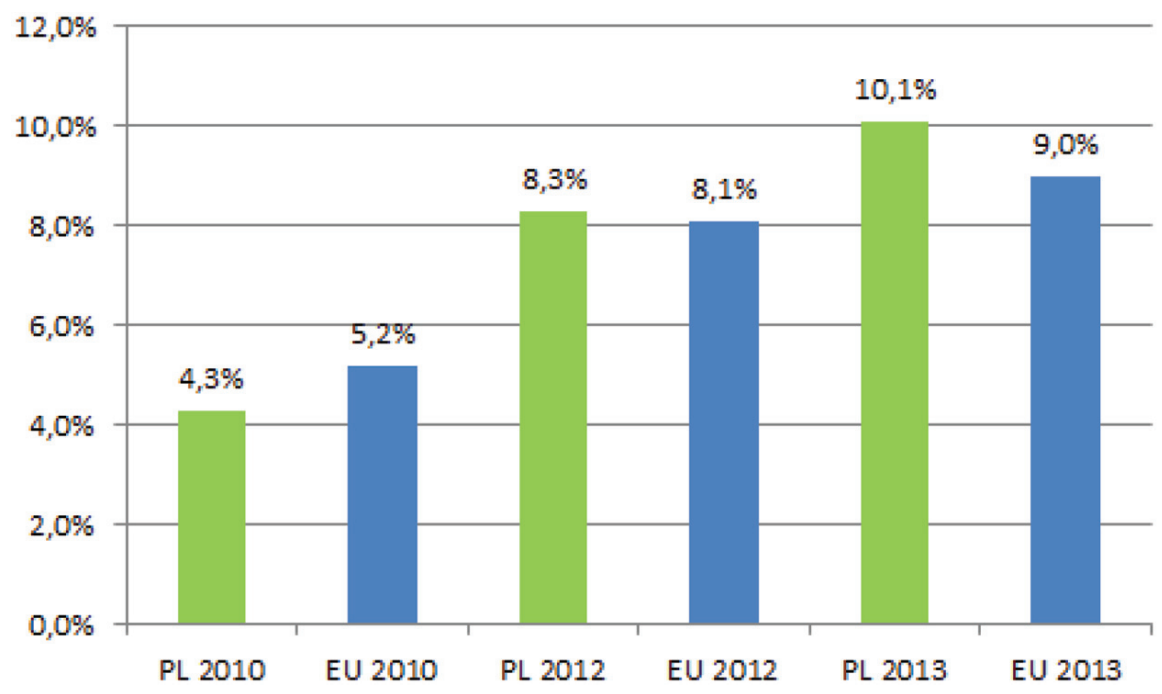

Figure 6 Mobile broadband penetration - dedicated data service cards/modems/keys only: Poland (PL) and EU average

Source: Digital Agenda Scoreboard 2013, Digital Agenda Scoreboard 2012, Fast and ultra-fast internet access; Digital Agenda Scoreboard 2011, Electronic Communications Market Indicators; Progress Report on the Single European Electronic Communications Market (15th Report).

\subsection{Mobile Broadband - 3G Modem}

The greatest dynamics of the development of the broadband service market in Poland is currently observed in the segment of mobile access. The boost of mobile broadband, including both data cards and smartphones started in $2011 .{ }^{4}$ Mobile broadband penetration, which refers to Internet access on third generation technologies and higher speed mobile technologies (i.e. HSPA or LTE), including modem/dongles is 74\% in January 2013 (EU average $54 \%$ ).

This increase was mainly due to a steep increase in the number of people using the Internet through smartphones. The penetration level of data cards (laptop devices) increased from $4.3 \%$ in 2010 to $8.3 \%$ in 2012 and to $10.1 \%$ in January 2013. Therefore, mobile broadband growth was driven mainly by the demand for handheld devices (smartphones or tablets) rather than by wireless access based on laptops.

Mobile broadband - dedicated data subscriptions for stand-alone services via cards/modems/keys only refers to the number of subscriptions to dedicated

\footnotetext{
${ }^{4}$ The Polish mobile market is well developed with seven mobile network operators.
} 
data services over a mobile network which are purchased separately from voice services as a stand-alone service (modem/dongle), i.e. excluding mobile handset users.

The figure above shows that wireless Internet market - dedicated mobile broadband cards/modems/keys is above the EU average by 1,1\% (January 2013), but is still at an early development stage. Even though operators are continuing to enhance their offerings for data cards/dongles, consumers are increasingly using smartphones to access the Internet.

Due to smaller size of the screen, lower speeds and lower quality for some application, mobile broadband Internet access on smartphones is used more as a complement to fixed broadband than as a substitute.

\subsection{Other Access Broadband Technologies}

Among other technologies the major role is played by wired LAN-Ethernet and wireless WLAN (jointly about 1.5 million people use them) ${ }^{5}$. The small share of the segment resulted from the specificity of LAN-Ethernet and WLAN services, which are provided to a narrow group of consumers, without any competitive alternative forms of access at home.

The remaining technologies constitute $1,8 \%$ of share in all types of lines used to provide Internet access service. ${ }^{6}$ It should be emphasised that within half a year the number of access optic-fibre lines (FTTC and FTTH) has increased by almost 100 per cent, which obviously does not significantly change the position of this technology in terms of share in the market.

\section{The Transformation of Regulatory Policies in Poland}

The public telecommunication policy and regulation enforced in Poland between 1990 and 2013 has undergone a fundamental transformation: from attempts to build a model based on free-market competition principles, through a period supporting the monopoly of the dominant operator, and further on to the stage characterized by the aggressive involvement of the market regulator with a clear focus on increasing service competition, to the current stage of

\footnotetext{
${ }^{5}$ Report on the telecommunication market in Poland in 2012, The President of the Office of Electronic Communications Warsaw, June 2013.

${ }^{6}$ Report on the telecommunication market in Poland in 2012, The President of the Office of Electronic Communications Warsaw, June 2013.
} 


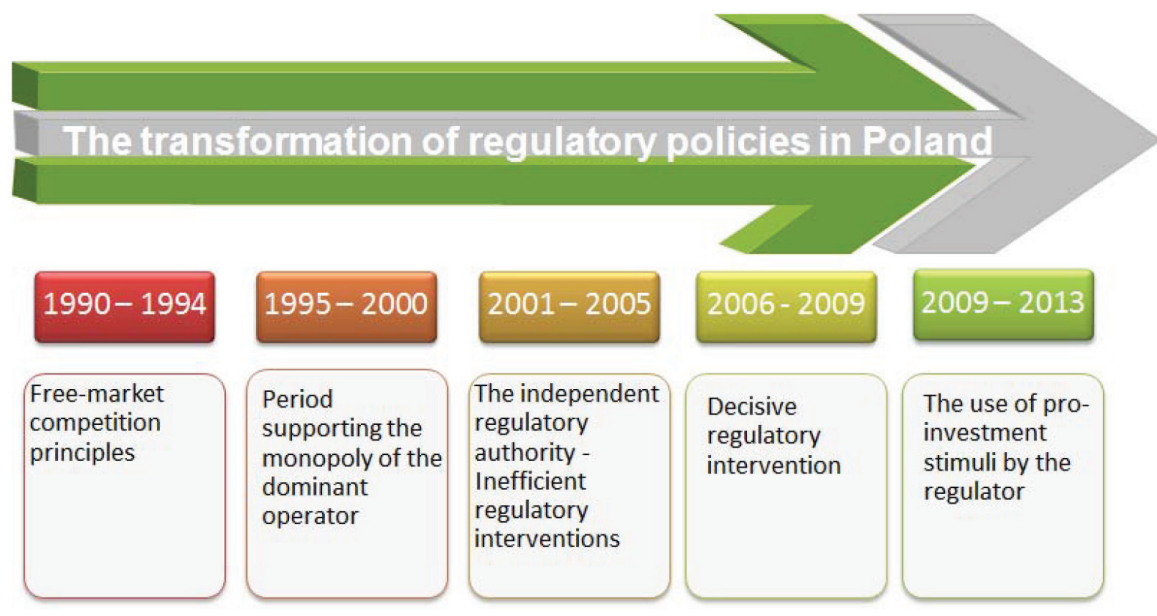

Figure 7 The transformation of regulatory policies in Poland

stimulation of the market with the use of pro-investment stimuli primarily in order to increase infrastructural penetration ${ }^{7}$.

\subsection{0-1994 Free-Market Competition Principles}

Poland was the first Central European country to enact a competition law and establish an enforcement agency after the collapse of communism in Central and Eastern Europe in the second half of 1989.

The first law concerning telecommunication regulation in the context of Poland's restructuring toward a market economy was adopted on 23 November 1990. The Communications Act of 1990 ended the state monopoly on the domestic services, but it retained the state monopoly on international services and its control over the domestic long-distance services ${ }^{8}$.

Even though the Act was very liberal and did not requisite capital or knowhow and did not provide grounds for refusal of licences, the investors realized that the Act was ineffective. It lacked the actual regulatory framework that would address specific problems relevant to business operations.

\footnotetext{
${ }^{7}$ A network of new opportunities, A Report on the Condition of the Telecommunications infrastructure in Poland Telecommunications Policy - Investment - Competition, Warsaw, November 2008.

${ }^{8}$ In 1990 TP S.A was established as a joint stock company with all its shares initially held by the government.
} 
In spite of the new legislation and the official declarations, the operators were not offered any support because the liberalization occurred simultaneously with the privatization of TP S.A.

The original assumption that competition would be the driving force behind the development of the telecommunication sector, and that the growth of Telekomunikacja Polska would stem from investment in the most profitable areas (international and long-distance communications) as well as a radical improvement in its operating efficiency, was practically abandoned. ${ }^{9}$

\subsection{5-2000 Period Supporting the Monopoly of the Dominant Operator}

The amendment to the Communications Act in 1995 sat up a regulatory regime of licencing for the provision of telecommunication services by tender. Major changes were related to the procedures of granting permits for the construction of telecommunication infrastructure and for performing services. TP S.A. was allowed to construct telecommunication networks and render services by virtue of the law, any other business entities had to apply for a permit or licence to the Minister of Communications.

It is important to point out that through the Ministry of Communications, the government maintained ownership of $100 \%$ of the TP S.A. shares. Before the privatization of TP S.A started, the State Treasury tried to maximise the sales value of TP S.A. shares through maintaining TP S.A. as monopoly.

Therefore, the potential for conflicts of interest were evident, and there were calls for a separate and independent regulator. ${ }^{10,11}$

\footnotetext{
${ }^{9}$ www.uke.gov.pl

${ }^{10}$ The above amendment to the Communication Act introduced significant restrictions in granting permits for establishing and operating cable TV networks. Such a permit could only be granted to the business entities in which the foreign capital share and voting share of foreign subjects on a shareholder's meeting or in a general assembly does not exceed $49 \%$ and additionally, in which the majority of members of management and of the board of directors are Polish citizens. These provisions prohibit to give permission for establishing and operating a multimedia network (cable TV and other telecommunications services including telephony) to any entity which doesn't comply with specified conditions.

${ }^{11}$ Under the 1990 Act and the amendment to the act in 1995, TP S.A took over responsibility for setting its own tariffs. Even though the Minister had the right to set ceiling tariffs, in practice, no maximum prices has ever been set and TPSA became the de facto regulator of prices.
} 


\subsection{1-2005 The Independent Regulatory Authority - Inefficient Regulatory Interventions}

The independent regulatory authority in the telecommunication sector was established by Telecommunications Law Act and began its operation on 01.01.2001 under the name of Telecommunications Regulatory Authority (Urząd Regulacji Telekomunikacji - URT) - as required by European Union directives. With the establishment of URT, the National Radiocommunications Agency and the National Telecommunications and Postal Inspection were liquidated. On 1 April 2002, in lieu of the then liquidated URT, the Office of Telecommunications and Post Regulation (Urząd Regulacji Telekomunikacji i Poczty - URTiP) was created. URTiP took over all the tasks, powers and duties of the URT in the telecommunication field. Transformation took place under the Act of 1 March 2002 on changes in the organization and functioning of central government authorities and their subordinate units and amendment of certain laws, Journal of Laws No 25, item 253 of 20 March 2002.

The situation in the Polish telecommunication market required a radical intervention by the Regulator mainly because of the strong position of the incumbent operator on the market, disproportionately high access charges, lack of competition, barriers to spreading broadband Internet access, and exclusion of inhabitants of rural regions.

The initiatives taken by the Regulator were mainly based on the control of the activities of the operator that has significant market share, and the support for the development of competition at the same time. However, because of an insufficient capacity of the Office of Telecommunications and Post Regulation $(\text { URTiP })^{12}$, the telecommunication market in Poland was still dominated by one operator - incumbent TP S.A. For example, TP S.A. maintained above 90\% market share in DSL access lines in 2004.

One of the ways of supporting effective competition on the telecommunication market was to enable companies to acquire authorisations to run telecommunication activities. In Poland, since 3rd September 2004, the acquisition of authorisations has undergone a significant simplification. Telecommunication activities started to depend only on entry in a register of telecommunication entrepreneurs. However, a more supportive realisation of liberal policies by the regulator could further contribute to an increased competition on the telecommunication market, especially with respect to providing broadband services by new companies. The regulator should facilitate activities of companies intending to provide telecommunication services to

\footnotetext{
${ }^{12}$ At present UKE.
} 
users attached to the network of other operators - e.g. regulations concerning access to the local subscriber loops, interconnection, and bit stream access.

The pressure to introduce unbundling came mainly with the development of broadband Internet services and the main goal of these unbundling policies was to stimulate competition in the telecommunication market.

But in 2005 the process of local loop unbundling was still in its initial phase. The reference offer for LLU for full and shared access dated 9 August 2005 did not bring about any real liberalisation of this market segment. Relatively high prices were the most important barrier. Therefore, on 10 May 2005 the President of the Office of Electronic Communications issued the "Offer specifying the reference terms and conditions for access to the local subscriber loop through access to the nodes of TP S.A. telecommunications network for the purpose of the sale of broadband data transmission services" - as the best solution to lower the prices and intensify competition on this market.

Until the end of 2006, not even one agreement on access had been concluded or a single TP subscriber line had been taken over by a competing operator.

There was also a significant problem in relation to the Reference Interconnect Offer (RIO). The publication of the RIO was considerably delayed by TP S.A. After the publication of the RIO in 2004 and 2005, it became apparent that the prices were higher than in other EU countries and their level not economically justified.

\subsection{6-2009 Decisive Regulatory Intervention}

Significant activity of the regulatory body has been noticeable only since January 2006, when UKE was set up in place of URTiP, and Anna Streżyńska became the President of UKE.

One of the first actions of the President of UKE in 2006 was the modification of the Reference Interconnection Offer, particularly the level of rates and payments for access to the TP telecommunication infrastructure whose level directly influenced retail prices. Flat Interconnection Rate, introduced in the TP Reference Interconnection Offer, allowed alternative operators to decrease prices of connection services for end users. The decision was immediately enforced.

It was necessary to adopt this decision in view of TP S.A. blocking competition development. The payments to TP S.A. in their Reference Leased Lines Offer (RLLO) greatly exceeded payments collected by other European operators, which seems to indicate that they have been considerably 
overpriced. The payments established by TP S.A. have been the cause of considerable delay of the development of market competition. Because of the above, it became necessary for the President of UKE to set leased lines prices at an average European level. Moreover, it was imperative for reference offers that the regulator introduced new rules considering conclusion, modification and termination of contracts between TP S.A. and alternative operators in the frame offer of May 10, 2006. The rules of contract conclusion greatly blocked the entry of new operators to the market.

In 2006, 11 alternative operators entered into agreements on leased lines with TP S.A. and six signed agreements on local loop unbundling. Moreover, operators also concluded interconnection agreements both with the incumbent and other alternative operators.

One should remember that until mid-2006, the settlement principles in force were those of TP's RIO approved by the NRA and published in June 2004, while after June 2006, interconnection agreements were concluded on new terms and conditions set out in the reference offer dated 4 July 2006 (Office of Electronic Communications, 2007).

The first bit stream access (BSA) deals with operators were signed by the end of 2006, enabling Netia and GTS Energis to start offering ADSL services to TP's customers in early 2007. By July 2007, 10 alternative operators have signed BSA deals with TP S.A. - Telefonia Dialog, Netia, GTS Energis, e-Tel, E-TELKO, ETOP, Dlugie Rozmowy, Tele2, Intertele, and Exatel, but only four have started offering services to their customers ${ }^{13}$.

The subsequent updating of reference offers for leased lines and the unbundling of the local loop and bit stream access by the President of the Office of Electronic Communications had brought about the conclusion of relevant agreements between the alternative operators and the incumbent.

The interconnection rates for the various services, adopted on the basis of the new RIO, had been reduced comparing to the years 2004-2006. This applied to all interconnection services provided by Telekomunikacja Polska S.A. to other fixed network operators.

In 2006-2008, an important step was taken by the Polish Government which had introduced a new regulatory outline for the telecommunication market. The main objectives of the short term strategy, which was devised by the Ministry, was increasing competition in the country's telecommunication market, decreasing the cost of telecommunication services for consumers, broadening consumers' access to new technologies, and to increase the

\footnotetext{
${ }^{13}$ www.uke.gov.pl
} 
efficiency of UKE. The UKE was responsible for taking the necessary measures in order to regulate co-operation between incumbent TP S.A. and alternative operators.

Therefore, between 2006 and 2008, the President of UKE's attention was drawn to typically interventional actions of which an example was an introduction of framework offers and regulations of retail prices. During this period, the President of UKE issued 36 decisions to impose financial penalties on telecommunication operators (mainly on TP S.A.) with a total value in excess of PLN 520 million ${ }^{14}$.

The President of UKE recognized that most barriers faced by alternative operators resulted from TP vertical integration. As a vertically integrated operator, TP was not interested in providing wholesale services to its competitors in the retail market and the incumbent abused its market power in order to hamper the operation of its competitors.

Therefore, many cases of negotiating agreements with TP ended up in requiring intervention by the President of UKE so as to ensure that reference offers function properly.

In order to address actual and potential problems with access to the incumbent's services, the President of UKE had decided to launch proceedings on imposing the obligation of functional separation on TP S.A. on December 2008.

Recognizing that functional separation is a far-reaching regulatory measure, TP S.A. began negotiations with the participants of the telecommunication market to improve the conditions of cooperation between operators. At the same time, the incumbent operator acted on its own initiative and in November 2008 the President of UKE was presented with proposals for actions to reduce the market problems indicated by the regulatory authority without the need for functional separation.

\subsection{9-2013 The Use of Pro-Investment Stimuli by the Regulator}

After public consultation on the draft submitted by TP S.A., and gathering a series of opinions on the possibilities and consequences of functional separation in August 2009 the President of UKE informally halted work on the separation of TP S.A. As a result of negotiations between the operator and the regulatory authority, an agreement was signed on 22 October 2009 titled

\footnotetext{
${ }^{14}$ www.uke.gov.pl
} 
the Equivalence Charter (Karta Równoważności), in which TPS.A. committed itself to the proper performance of all regulatory duties imposed on it and to the implementation of a series of actions to ensure transparency and nondiscrimination in relations between operators, in return for the withholding of measures undertaken by UKE towards functional separation of the company ${ }^{15}$.

TP S.A. obliged itself to separate a unit dealing with the provision of wholesale services from its structure and to limit the discriminating flow of illicit information both within the company itself and among the entities being part of the TP Group. One of the most important provisions of the Agreement has been the obligation to build or modernize at least 1.2 million broadband lines. The obligation is included in the other infrastructural initiatives of the President of UKE.

The Equivalence Charter assumed the resolution of problems reported by the market and the regulatory authority based on voluntary actions and cooperation of $\mathrm{TP}$ with the regulatory authority and alternative operators $(\mathrm{AO})$, and not through administrative orders. In addition, the implementation of the Equivalence Charter is to be less expensive and the effects are to be achieved within a shorter time than they would with functional separation.

One of the most important elements enabling the assessment of the impact of the agreement is the state of implementation of TP's investment commitments associated with the development of broadband infrastructure. During the first 24 months of the Agreement, TP has built a total of 683,933 lines, including 100.7 thousand in the so-called blank spots - locations where, due to the economic balance, the investment would not have been taken up by any operator. In January 2012, the timeframe for investments has been extended from 31 December 2011 to 31 March 2013, in exchange for higher speeds (220 thousand lines - $30 \mathrm{Mbps}$ instead of 6Mbps) however still on copper.

The next step towards removing barriers to access to broadband Internet and development of telecommunication network was the adoption of the "Act on promotion of development of telecommunications networks and services" (7.05.2010). ${ }^{16}$ It is expected that the new regulations will significantly accelerate the development of telecommunication investments and facilitate

\footnotetext{
${ }^{15}$ The agreement between TP and the President of UKE. Communication of 22.10.2009 http://www.uke.gov.pl/uke/index.jsp?Lead02\&place=news_cat_id=19\&news_id=4750\&layo $\mathrm{ut}=1 \&$ page $=$ text

${ }^{16}$ On 10 December 2012 the President of Poland signed an act amending the Telecommunications Law to implement the EU Directives issued in 2009. The majority of the amendments entered into force on 21 January 2013.
} 
the process of disbursement of EU funds for the development of broadband Internet access.

New legislation authorizes local governments and authorities for telecommunication activities, such as network and services provision. The new "rights of way" impose obligations on commodities enterprises, such as public ways, electrical, water and sewage companies, to share their infrastructures with telecommunication operators. The construction law is modified implementing simplified procedures of construction licensing and project approvals. New competencies are given to the electronic communication regulator, including right to appeal any local prohibition against new telecommunication investments, including radio communication masts and stations. The common aims of these rules is to fasten and make easier investment processes in the telecommunication sector, especially in new regional broadband infrastructure, new generation access networks (including wireless networks) and new service platforms ${ }^{17}$.

As we can see, between 2009 and 2013 the Office of Electronic Communications UKE stimulated market developments with the use of pro-investment stimuli primarily in order to increase infrastructural penetration.

The 5-year term of office of the President of UKE Anna Strezynska finished in January 2012. A new President Magdalena Gaj was appointed by the Polish Parliament on 27 January 2012, and she continues the work of her predecessor.

The regulatory policy enforced so far by the President of the Office of Electronic Communications (UKE) focused mainly on increasing the accessibility and usage of services and has not put much emphasis on the issues of the development of the telecommunication infrastructure. The new President of UKE continues exploring different incentives to stimulate investment in broadband infrastructure. The President believes that the new act will encourage wider investments in the telecommunication sector and will bring higher penetration of broadband access and new services.

\section{National Policies Stimulating Broadband Development}

Poland's strategies for the ICT sector have evolved through a series of key documents that guide its path towards the Information Society.

The first strategy "Aims and Directions of the Information Society Development in Poland" was based on seven reports conducted in the Context

\footnotetext{
${ }^{17}$ The Act of 7 May 2010 on supporting the development of telecommunications services and networks.
} 
of Poland's Accession to the EU. Among its objectives, the strategy included: strengthening the Polish economy, enabling universal access, and facilitating the use of ICT by the public sector to ensure greater efficiency and assist in the establishment of open, transparent and citizen-friendly structures of public administration.

In September 2001 the Ministry of Economy prepared the Strategy called "e-Poland 2006 - The Action Plan for the Information Society Development in Poland for the years 2001-2006"18. The Strategy was based on the Lisbon Strategy and the "eEurope" initiatives. The strategy was being prepared in a hurry (from June to September 2001). Thus, in result, although the complex document was delivered, it settled too many priorities that made this document inoperable ${ }^{19}$.

Therefore, the strategy has been improved in the consecutive document: Strategy of Informatization of the Polish Republic - ePoland for years 2004-2006 delivered in December 2003. The priority projects were indicated there, final results and deadlines determined and responsible institutions appointed.

Twelve key actions have been defined within the above document. Among them the following were selected as critical for the computerisation of Poland:

- the "Gateway to Poland" (an integrated platform of public administration services available to a knowledge-based society),

- broadband Internet access in every school,

- Polish content on the Internet,

- a commonly available IT education.

The Strategy was accompanied by a programme of works which included a series of projects allocated under each strategic objective. The programme of works included specific projects which were considered key contributors to the eventual increase of broadband in Poland, such as:

- Internet for School - to give access for all 43000 schools

- IKONKA - computers and Internet in 2470 Public Libraries

- PIAP - Public Internet Access Points in each of 3200 counties

- CKS - Social Communication Centers in rural Post Offices

\footnotetext{
${ }^{18}$ ePoland - The Strategy on the Development of the Information Society in Poland for the years 2004-2006.

${ }^{19}$ A. Demczuk, A. Pawlowska, D. Woźniak, E-Public Services in Poland - The State of the Art, Paper for Working Group on eGovernment NISPAcee Annual Conference, Moscow, May19-21, 2005.
} 
- Public Information Bulletin - web page in each public office

- Local Information Centers - electronic employment offices

- Polish Internet Library - culture and historical archives

- PIONIER - ultra high capacity net for science (up to Tbits/sec)

- SIMIK - IT system supporting EU projects in all phases

- Public Service Systems - visas, car registration, medical registers

- Banking Information Register - online service for all banks

- e-Signature - 4 secure certification companies

- Local projects - acc. to 16 Regional Development Plans

\subsection{Different Modes of Public Policy Intervention in Poland}

Policies lay down the basic framework for government operations and provide a clear picture to all stakeholders about expected outcomes and related responsibilities.

Various types of policy orientations come to light while developing policies to support broadband development:

- Strengthening and harmonisation of internal use in public organisations

- Developing public communication networks and services relating to citizens and businesses

- Facilitation of the development of communication networks and services

- Regulation proper, setting the 'rules of the game'

- Support for demand

- Support for supply

We have classified the above mentioned policy initiatives based on forms of intervention as follows:

1. The lightest forms of intervention

2. Facilitation

3. The strongest forms of Intervention

\subsubsection{The lightest forms of intervention - E-government initiatives}

There is a close relationship between broadband penetration and citizen uptake of e-government services. This presents an important challenge for Poland, where broadband penetration remains limited.

In Poland, activities concerning advances in e-administration were structured in "Gateway to Poland". The "Gateway to Poland" Action Plan proposes the creation of an integrated platform for the provision of public services online. 


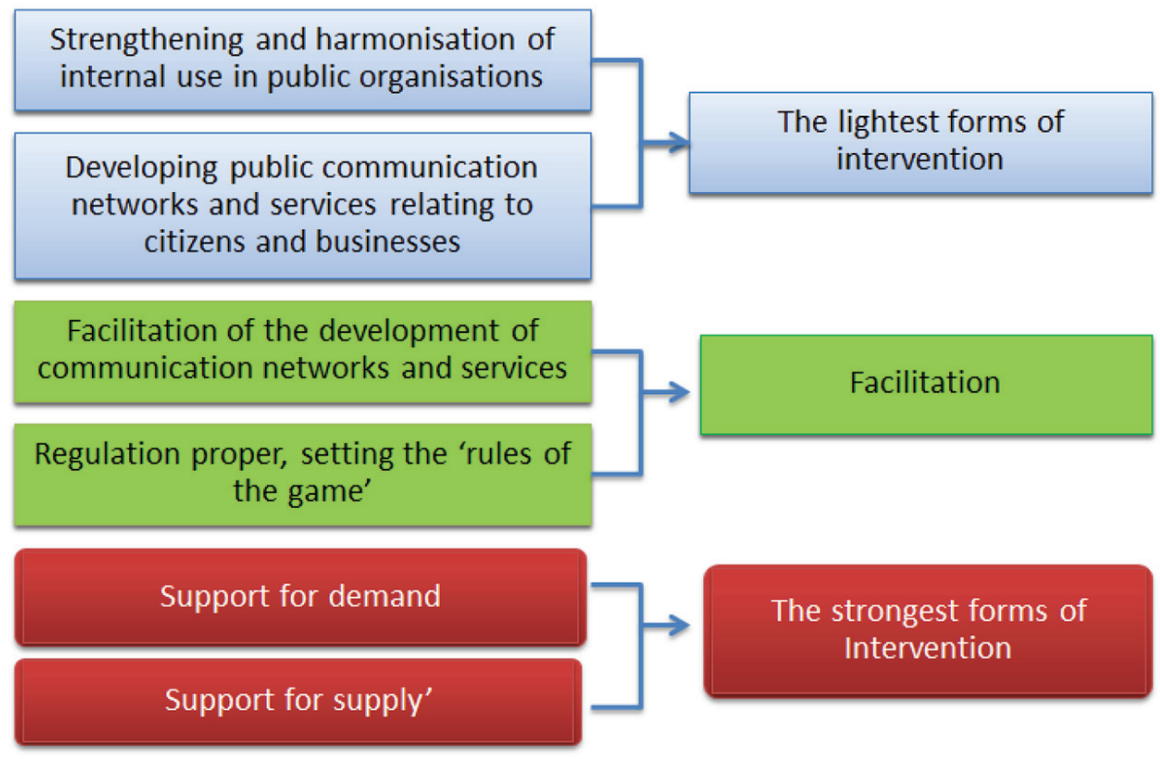

Figure 8 Policy initiatives based on forms of intervention

Even though the main focus of Polish national e-strategies was on e-government, in the years 2002-2004 only $2 \%{ }^{20}$ of public services surveyed were fully available online. ${ }^{21}$

Therefore, the new initiative "Action Plan for the Development of Electronic Government (e-government) for the years 2005-2006" was established. The e-Government Action Plan derived from the Strategy on the Information Society Development - ePoland for the years 2004-2006.

Even though several projects were implemented, there has been no dramatic increase in the number of Internet users, and no acceleration in the computerization of government bodies. It is important to point out that many activities covered by the action plan were implemented with significant delays (by February 2008, only two of the planned 16 projects (e-Deklaracje and e-PUAP) were delivered. Due to the delays, certain initiatives lost their sources of funding (e.g. the PESEL 2 project has lost a large part of EU subsidies).

An example of a successful e-government implementation is the project "The Construction of an Electronic Platform for Government

\footnotetext{
${ }^{20}$ According to European Commission scoring framework, in the years 2002-2004, Polish e-Government reached the level amounting to $2 \%$.

${ }^{21}$ http://www.epractice.eu/files/media/media_240.pdf
} 
Services - ePUAP". ePUAP is a national information system for access to e-government services such $\mathrm{C} 2 \mathrm{G} / \mathrm{G} 2 \mathrm{C}, \mathrm{B} 2 \mathrm{G} / \mathrm{G} 2 \mathrm{~B}$ and $\mathrm{G} 2 \mathrm{G}$. The system was built in 2006-2008. The basic task of this platform was to make accessible electronic services for public administration subjects, especially for small ones, who have no possibilities or needs to develop their own huge and separate systems.

The ePUAP2 project is being implemented in the years 2009-2013. It aims to extend the functionality of the ePUAP system and to increase the range of services provided electronically.

Even though during the last few years some e-Government applications have been rolled out, an e-Government structure building in Poland is still pending. This is the result of delays in an informatisation of public administration entities. No complex projects from the government's informatisation strategy have been finalized and many of them are seriously delayed. For example, plans to digitize key government services are set to be delayed until 2016 due to alleged corruption during the bidding process and fears of vendor lock-in in relation to the proposed new IT services. Use of the system was originally due to start at the end of 2014.

Due to concerns about the legality and regularity of expenditure and low management efficiency of EU funding, the EU Commission decided to discontinue payments to Polish electronic projects (e-government) in April 2012.

However, in September 2012 the European Commission announced the release of funds for Poland's e-Government projects. This decision comes as result of the new plan, undertaken by the Ministry of Administration and Digitisation. The Ministry has made public procedures and responsibility requirements at every stage of a project. According to the new plan, each stage of the project should be assessed not only on the basis of the amount of money spent but also on the performance objectives. This decision enabled to continue the following projects:

- The eTaxation project (ePodatki, in Polish) enables citizens to carry out their taxation obligations online;

- The Central Register and Information on Business (Centralnej Ewidencji i Informacji o Działalności Gospodarczej - CEIDG, in Polish) allows interested people to set up a business online;

- The National Court Register (Krajowy Rejestr Sądowy OnLine - KRS, in Polish) enables online access to copies of the National Court Register; 
- The eServices platform of the Social Insurance Institution (Zakład Ubezpieczeń Społecznych - ZUS - PUE, in Polish) gives access to data recorded in one's individual pensions account, yet another reason for having a Trusted Profile, which is a free electronic signature thanks to which citizens can settle administrative matters electronically;

- Online access to mortgage records - interested people can get a copy of the land register record with only their registration number;

- Location and Information Platform with a Central Database (PLI CBD): A quick way to identify the place from which the call to the emergency number is made. This is important in case the victim or witness of an event does not know the exact location of the incident or for safety/health reasons, they are not able to give this information or in case one's property is threatened, for example in the event of fire. ${ }^{22}$

According to the 2012 edition of the United Nations e-Government Survey, Poland is ranked 47, while in 2010 Poland was on the 45th and in 2008 on 33th place. ${ }^{23}$

\subsubsection{Facilitation}

Facilitation of the development of communication networks and services include increasing transparency in the markets by way of public information on qualities and prices of communication networks and services.

The regulatory authority in Poland plays an active role in providing information on prices, on geographical availability and on product/service description.

On 12 May 2009 on the initiative of the President of the Office of Electronic Communications, a website of the National Broadband Forum was launched. The main goal of the National Broadband Forum is to create a communication platform between the groups for which the development of broadband access services and activation of society in this regard is important. UKE directs this project to the local government units as potential investors in broadband roll-out and to people searching for optimal technological solutions for the implementation of investment projects. ${ }^{24}$

In order to speed up investment in the telecommunication sector, to optimize utilization of public money and UE founds, and define white and

\footnotetext{
${ }^{22}$ http://www.epractice.eu/en/news/5395526

${ }^{23}$ United Nations E-Government for the People, United Nations, New York, 2012.

${ }^{24}$ The National Broadband Forum, UKE, 2009.
} 
grey areas in Poland, The Information Broadband Infrastructure System $(\text { SIIS })^{25}$ was established. It's a computer system for gathering, processing, presentation and sharing information about telecommunication infrastructure, public telecommunication networks and buildings to enable collocation. First report about broadband telecommunication infrastructure was published 30 of June 2011. Already in November 2011 a new version of SIIS with improved data input functionality, dedicated functionality for reports, and presentation of infrastructure on the maps was implemented.

\subsubsection{The strongest forms of intervention - support for supply and demand}

Supply-side strategies can directly encourage investment in broadband infrastructure and demand-side strategies can generate revenue streams to sustain infrastructure development.

Poland has low broadband penetration and should, consequently, focus on policies that promote both supply- and demand-side of the broadband market. Promotional policies can promote the supply side, such as inducing investment in the broadband network, and the demand side, such as raising citizen awareness about broadband benefits and easing subscription barriers.

Even though it is generally accepted that the private sector should be the primary driver of broadband development, in certain instances competition and market forces will not be sufficient for broadband to develop. Due to factors such as geography or low population density, private sector players in Poland are unwilling to invest capital where they perceive that they will get a low (or no) return on their investment. For these areas, it is necessary for the government to intervene more directly to ensure that underserved areas and populations are able to get access to broadband networks and services.

\subsection{Demand-Side Policies}

Demand promotion policies refer to efforts to boost the use of broadband by raising awareness of its possible benefits as well as making it affordable and more attractive to users.

Poland takes a proactive approach to demand stimulation, using structural funds for systematic enhancement of the amount and quality of online

\footnotetext{
${ }^{25}$ Funded by the Operational Program Innovative Economy 2007-2013, implemented within The Information Broadband Infrastructure System Project and Poland Broadband Portal (SIPS). The Project is implemented by Institute of Communication (Polish research unit), Office of Electronic Communication and Ministry of Infrastructure.
} 
digital content from sources of general interest, e.g. the digitization of all kinds of material and archives from museums, libraries and other sources of cultural content such as broadcasts. Because most of the content selected for digitization is potentially bandwidth-intensive material, this will help to stimulate demand for higher speeds in the future.

In 2012, Poland's Library Development Program won the 2012 e-inclusion awards for best practice in e-inclusion across Europe. The primary objective of the Library Development Program (2009-2014) of the Information Society Development Foundation (FRSI) is to provide equal opportunities for the underserved population living in rural areas. This has been achieved by revitalizing local libraries and providing them with multimedia equipment and internet access. The initiative covers more than 3,300 libraries servicing 10.6 million inhabitants. It has provided internet access to c. 750,000 people, half of which have never used the internet. The libraries participating in the program assist more than 50,000 people annually, offering group classes and individual consultations on hardware and internet usage. ${ }^{26}$

In addition, structural funds are used to subsidise internet access, computer equipment, and training for less well-off people or those with disabilities. This support seems particularly important taking into consideration the fact that in 2008 , as many as $68.9 \%$ of people with legal disability status (aged 16-74) had never used a computer and $75.0 \%$ the internet.

Recognizing the importance of a digitally literate population, Poland has set up a customised digital education program for the 50+ age bracket and inhabitants of sparsely populated regions. According to "Cities on the Internet" Association (COI) close to 13 million Poles are lacking elementary skills to profit from the content and services offered by the Internet, they also lack fundamental knowledge on the use of ICT in daily life and work ${ }^{27}$. The ultimate goal of the project is to introduce 60000 people from the $50+$ generation into the digital world. The project is being realized with the involvement of 2600 "Lighthouse Keepers" - Polish local digital champions: trusted, creative local community leaders/animators tasked with introducing 50+ adults from their own communities into the digital world. Activities of all Lighthouse Keepers complement a nationwide digital competence raising program targeting digitally excluded, which

\footnotetext{
${ }^{26} \mathrm{http} / / /$ www.e-inclusionawards.eu/2012-winners/winner-library-development-programmefrsi/

${ }^{27}$ Narodowy Plan Szerokopasmowy, - perspektywa 2020 r., Warszawa 2012.
} 
at the same time will stimulate the demand for broadband access to the Internet.

In addition, Poland has launched several other initiatives in the area of e-health and e-learning. For example, the Polish e-health strategy "The Plan of the Informatisation for e-Health for the years 2010-2015" defines key goals and activities for the further development of an eHealth system in Poland and refers to the EU eHealth Action Plan (2004). Establishment of an IT infrastructure for Polish healthcare is very important in order for Poland to become a member of the Electronic Health Record Area in Europe.

In order to foster the provision of private-sector online services, Poland has established a scheme to co-fund the creation of online offerings by start-up SMEs. These activities are complemented by measures to tackle digital exclusion. To this end, structural funds are used to subsidise internet access, computer equipment and training for less well-off people or those with disabilities. $^{28}$

\subsection{Supply-Side Policies}

Direct development of broadband infrastructures by national governments and local communities is clearly one of the strongest the forms of intervention. Under certain conditions it is recommended to use public funds to extend broadband coverage in areas where there is no incentive for commercial operators to invest in and accelerate the deployment of very high speed, next generation access networks.

As telecommunication infrastructure is crucial and fundamental to using e-services, the government recognized that without the proper infrastructure, e-strategies are less likely to succeed. This is why some of the ICT strategies specify telecommunication infrastructure as an area of focus.

One of the most successful projects in relation to the development of the infrastructure was "PIONIER -Polish Optical Internet - Advanced Applications, Services and Technologies for the Information Society (2001-2005)"

The strategic aim of this project was to build a country-wide optical network connecting all academic and metropolitan networks in Poland and to provide scientists with access to an advanced network infrastructure. The plan also included the expansion of the PIONIER network across Poland

\footnotetext{
${ }^{28}$ Commission Staff Working Document on the Implementation of National Broadband Plans, EC, Brussels, 23.3.2012.
} 
$(6000 \mathrm{~km})$ and to provide new broadband connections to neighbouring countries (Lithuania, Slovakia, Belarus, Ukraine).

The program focused on three areas:

1. Construction of broadband network infrastructure supporting the science communities, matching similar installations in other European countries

2. Development and verification of pilot services and applications for the information society, creating a base for new developments in science, education, health care, natural environment, government and local administration, industry and services

3. Creation of competitive conditions for active software development for new applications in the information society

As a result of this program, the following infrastructure has been built:

- 5 high performance computing centres (HPC) in Warsaw, Cracow, Poznan, Gdansk and Wroclaw

- 22 metropolitan area networks (MAN) in main research centres, based on their own fibre cables with ATM technology up to $622 \mathrm{Mbps}$

- 2 operating national networks - the Scientific and Academic Network (NASK) and broadband research and education network POL-34 operated by Poznan Supercomputing and Networking Centre

- Connection of the Polish research and education networks to the European Network TEN-155.

- Over 700 academic units, including universities, institutes of Polish Academy of Sciences, hospitals, libraries, industrial R\&D institutes

- About $3000 \mathrm{~km}$ length (optic fibres)

PIONIER network was built entirely from the KBN (Polish Committee for Scientific Research) funds. It, currently, connects 21 Academic Network Centers of Metropolitan Area Networks (MAN) and 5 of the HPC (High Performance Computing) Centers using their own fiber connections. PIONIER is Europe's first national academic network that uses its own dark fiber optics and DWDM 10GE transmission.

In 2011/2012 the Polish authorities has decided to grant public aid to the construction of a backbone and distribution infrastructure ${ }^{29}$. According to the

\footnotetext{
${ }^{29}$ The subsidy will cover mostly passive elements, which are indispensable for installation and running of broadband access to Internet (such as e.g., ducts, cables, optical fibres, manholes, telecommunications racks, or other locations of telecommunications nodes) as well as active elements, if it is necessary to accomplish the projected goal (mostly in the nodes of backbone network and in the main nodes of distribution network) within the available budget, www.uke.gov.pl
} 
Polish authorities, the problem of the lack of supply of broadband networks, particularly in rural areas, can't be solved entirely by measures involving demand stimulation or regulatory interventions.

The National Regulatory Authority (UKE) decided to support five Voivodships of Eastern Poland ${ }^{30}$ due to the fact that the average income of inhabitants is low in comparison with other regions in Poland, and the population densities in these Voivodships are among the lowest in the country. In connection with the above, the development of broadband in Eastern Poland faces two key problems: the lack of infrastructure to deliver the services required by the public authorities and by citizens and the lack of adequate competition reflected in high prices or inadequate services. According to the Polish authorities, in as many as 10,501 localities out of the 15,298 total, there is no optical distribution node, and there is no broadband access to Internet offered that would guarantee $2 \mathrm{Mbit} / \mathrm{s}$ download speed to end-user. As far as the NGA infrastructure is concerned, among 15,298 localities in Eastern Poland there are only 1,153 where NGA services are offered or are planned to be offered in the next 3 years, and even there it is usually the case only in small parts of these localities, with the highest density of population ${ }^{31}$.

The Polish authorities contend that a market failure is present in those areas as regards the provision of NGA services and, in some areas, also of basic broadband services and therefore, they consider state intervention necessary to correct it.

According to the Polish authorities, the main reason for the low level of accessibility of broadband services is the physical absence of sufficient fiber optic broadband distribution infrastructure and 'last mile' infrastructure. Consequently, the Polish authorities decided to carry out rollout of a new broadband network in Eastern Poland, which will lead to the removal of this infrastructure gap.

The total budget of the project amounts to approx. PLN 1,444,400,000 PLN (approx. EUR 352,300,000) ${ }^{32}$. A significant part of the funding will come from ERDF $^{33}$ - EUR 255 million, and the remaining amount will come from the state budget and from the budgets of the regional governments of the five Eastern Poland Voivodships. The project envisages that during the

\footnotetext{
${ }^{30}$ Lubelskie, Podkarpackie, Podlaskie, świętokrzyskie, Warmińsko-Mazurskie with a total population of approx. 8.162.000 inhabitants.

${ }^{31}$ Broadband network project in Eastern Poland, EU, Brussels, 10.11.2011.

${ }^{32}$ The final total budget of the project might be increased by up to approx. EUR 40 million. The planned allocation of amounts among voivodships is also subject to change.

${ }^{33}$ ERDF European Regional Development Fund.
} 
term of contract with the Infrastructure Operator, the respective Voivodship will remain the owner of the network. The Infrastructure Operator (IO) shall not provide any services to end-users, but only provide wholesale services to other telecommunication operators. The Infrastructure operator will have an obligation to provide effective wholesale access to third parties during the whole term of the contract with the Voivodship i.e. for a period not shorter than 7 years.

It is important to point out that state intervention to support broadband deployment in Poland fulfills the conditions defined by European Commission.

\section{Conclusion}

In this paper we have presented the wide range of regulatory and policy tools that have been adopted in Poland in order to stimulate the investment in infrastructure and take-up of broadband services.

Regulation has been used in order to promote competition in the Polish market. The strengths of the regulatory regime in Poland came from the new regulatory policy initiated by the President of UKE in 2006 and from the new Telecommunication Law that is designed to promote competition.

The introduction of mechanisms that enable access to infrastructure of an operator with a significant market power was one of the most effective mechanisms influencing market competitiveness. This intervention has helped to establish prices for wholesale in the framework offers at levels that enabled alternative operators to build an attractive retail offer for broadband data transfer services for residential and business customers.

Despite the crucial role of regulation in ensuring competition in the market, evidence shows that in some areas of Eastern Poland regulation has not fully been able to ensure effective competition and has not led to sufficient investments in broadband infrastructure. As we can see from Polish experience, regulation is, indeed, a necessary, but not a sufficient instrument for the development of broadband infrastructure and services. Alternative providers need to combine the use of wholesale products from the incumbent with own network investments which may not be profitable in rural areas where demand is low.

In order to reduce the broadband development differences, various countries have EU funds at their disposal. Such means should help financing the 
infrastructure investments which need to be of a huge scale. ${ }^{34}$ Unfortunately until now, EU funds for the support of telecommunication infrastructure development in Poland have been greatly underutilized.

According to the Supreme Audit Office NIK $^{35}$ most of the planned investments related to the creation of the broadband Internet have either barely started or stopped at the stage of preparation.

The European Union granted more than EUR 1 billion to Poland (2007-2013) for the creation of broadband networks ${ }^{36}$. Payment made to beneficiaries, as of August 31, 2011, was only $4.41 \%$ of the allocation.

The above data reflect the fact that the assumed objectives of the operational programmes may not be met. What follows, the EU grants will have to be returned.

Local governments are among the institution hindering broadband development in Poland even though the most numerous group of structural funding beneficiaries are in fact the local governments. They are treating investments in broadband Internet access as secondary to other investments in roads and transport infrastructure, as well as general public amenities and social facilities.

Even though EU founds could also have covered enterprises, they were not interested in the development of telecommunication infrastructure due to legal problems and problems in connecting the local networks to the backbone infrastructure owned by Polish incumbent TP S.A. This situation resulted from the fact that the Polish Telecom Regulator (UKE) has proposed not to regulate the prices alternative operators pay for wholesale broadband access to TP's fibre-to-the-home (FTTH) network, meaning that $\mathrm{TP}$ would determine this access price. UKE believes that such pricing freedom will give an incentive to TP to further roll out such networks. ${ }^{37}$

\footnotetext{
${ }^{34}$ For example, the Polish "National Computerization Plan" envisages that most publicadministration computerization projects will be to a large extent financed from the EU sources, such as the EU Regional Development Fund (even up to $85 \%$ of the project value in some cases).

${ }^{35}$ The Supreme Audit Office (NIK) - is the top independent state audit body whose mission is to safeguard public spending. The NIK has been assessing the functioning of the Polish state and public funds management.

${ }^{36}$ NIK Report on the Internet access and telecommunications services, www.nik.gov.pl, Warsaw 20.06.2012.

${ }^{37}$ Digital Agenda - Commission calls on Polish telecoms regulator to improve access to fibre network, EC, August, 2012.
} 
The problem seems to be in finding the right balance between giving operators the incentive to invest in broadband network and safeguarding competition on the market.

There are still large differences between urban and rural areas both in regards to broadband infrastructure development and in regards to use of online services.

Even though demand promotion policies have focused on the development of public sector applications such as e-health, e-learning and the provision of broadband access to public institutions, online availability of public services is still below the European average and the take-up is still low in Poland. In this respect, demand side policies should be directed towards the content and educational aspects, in order to increase knowledge about computers, internet and advantages of the use of e-services in the field of public administration.

\section{References}

[1] Bartoszewska, B., Duszak, M. (2005). System of periodical reports, relating to the development of the market of telecommunication services, competition and entities acting on this market, National Institute of Telecommunications, Warsaw, September 2005.

[2] Bauer, J. M. et al. (2004). Effects of national policy on the diffusion of broadband in the OECD countries, paper prepared for presentation at the UFL-LBS workshop in Gainsville, Florida, 24-25 February 2004.

[3] Broadband network project in Eastern Poland, EU, Brussels, 10.11.2011

[4] Central Statistical Office, Concise Statistical Yearbook of Poland (2007). http://www.stat.gov.pl/cps/rde/xbcr/gus/PUBL_maly_rocznik_statystycz ny_2007.pdf

[5] Central Statistical Office (2005). ICT usage in households and by individuals in 2004, Warsaw 2005.

[6] Cieślak, D., Żmijewski, M. (2005). Polish Broadband, PC World Komputer, April 2006.

[7] Commission of the European Communities. (2006). European Electronic Communications Regulation and Markets 2005 (11th Report), Brussels, 20.02.2006, SEC(2006)193.

[8] Commission of the European Communities (2006). Bridging the broadband gap, Brussels, 20.3.2006,

[9] Commission Staff Working Document on the Implementation of National Broadband Plans, EC, Brussels, 23.3.2012 
[10] Demczuk A., A. Pawlowska, D. Woźniak, E-Public Services in Poland - The State of the Art, Paper for Working Group on eGovernment NISPAcee Annual Conference, Moscow, May19-21, 2005

[11] Digital Agenda - Commission calls on Polish telecoms regulator to improve access to fibre network, EC, August, 2012.

[12] Digital Agenda Scoreboard 2013, EC, Brussels, 12.06.2013

[13] ePoland - The Strategy on the Development of the Information Society in Poland for the years 2004-2006

[14] European Commission (2005). Broadband access in the EU: situation at 1 January 2005, Communications Committee, Working Document, COCOM05-12 Final. Brussels, June 2005.

[15] European Commission (2007), Communications Committee, Working Document, Broadband access in the EU: situation at 1 January 2007, Brussels, 27 July 2007.

[16] Falch, M. (2007). Penetration of broadband services - The role of policies, Telematics and Informatics, issue 4, pp. 246-258.

[17] Fransman, M. (2006). Global broadband battles - Why the US and Europe lag while Asia leads, Stanford University Press.

[18] Frieden, R. (2005). Lessons from broadband development in Canada, Japan, Korea and the United States, Telecommunications Policy, 29(8), pp. 595-613.

[19] Henten, A. (2001). Optimal framework conditions for ICT development, in Proceedings IST 2001, September 2001, Tehran, Iran, pp. 507-510.

[20] Henten, A., and Falch, M. (2007). Information society industrial policy, in Ari-Veikko Anttiroiko and Matti Mälkiä, Encyclopedia of digital government, vol. III, Idea Group, Hershey, 2007, pp. 1064-1068.

[21] Internetworldstats (2007). www.internetworldstats.com

[22] Kamiński, F. (2003). The role of the state in the development of telecommunication, historical experiences, Telecommunications and Information Technologies, National Institute of Telecommunications, Warsaw, March 2003,

[23] Klejber, M. (2005). Information Society in Poland. How far are we? Minister of Scientific Research and Information Technology, XV Economic Forum Krynica, September 2005.

[24] Ladny P., Windekilde I., Broadband development in Poland, The Dynamics of Broadband Markets in Europe, Delft University of Technology, 2012

[25] Multiple trajectories in realizing the Digital Agenda targets 
[26] Ministry of Economy (2001), ePolska (ePoland) - The Action Plan for the Information Society Development in Poland for the years 2001-2006, 11 September 2001, http://www.kbn.gov.pl/

[27] Ministry of Education and Science in Poland (2003). National Strategy for the Development of Broadband Internet Access for 2004-2006, December 2003.

[28] Minister of Science and Information Society Technologies (2005), National Development Plan 2007-2013, Warsaw, August 2005, p. 22

[29] Miralles, F. (2006). Efficiency of public policy promotions policies in the diffusion of broadband networks - An Exploratory analysis, presented at the $34^{\text {th }}$ TPRC, Virginia, September 2006.

[30] Narodowy Plan Szerokopasmowy, - perspektywa 2020 r., Warszawa 2012

[31] Netia SA Reports 2007 First Quarter Results, Warsaw, Poland - May 15, 2007

[32] NIK Report on the Internet access and telecommunications services, www.nik.gov.pl, Warsaw 20.06.2012

[33] OECD (2004). Broadband Statistics, OECD, December 2004. Available at http://www.oecd.org/

[34] OECD (2006). Broadband Statistics, OECD, December 2006 Available at http://www.oecd.org/,

[35] Picot, A. and Wernick, C. (2007). The role of government in broadband access, Telecommunications Policy, issue 10-11, pp. 660-674.

[36] Pionier Program, http://www.pionier.gov.pl/project/program.htm

[37] Regulatory reform in the telecommunications industry, OECD, 2002

[38] Raport o stanie rynku telekomunikacyjnego w Polsce w 2011 roku, UKE, Warszawa, June 2012

[39] Report on the telecommunication market in Poland in 2010, the President of UKE, Warsaw, June 2011

[40] Report on the Condition of the Telecommunications infrastructure in Poland Telecommunications Policy - Investment - Competition, A network of new opportunities, Warsaw, November 2008

[41] Supreme Chamber of Control (2006), Report October 2006, www.nik.gov.pl

[42] The agreement between TP and the President of UKE, Communication of 22.10.2009

[43] The Act of 7 May 2010 on supporting the development of telecommunications services and networks, Warsaw 2010 
[44] The President of the Office of Electronic Communications (2006), Reference Interconnection Offer, the decision no DRT-WWM-60629/04(226), Warsaw, Poland, May 2006.

[45] The Polish Chamber of Information Technology and Telecommunications (2005). The terms of the development of the communication market in the Poland in 2005-2007, Warsaw, Poland, June 2005.

[46] The Office of Electronic Communications (2006). The level of the prices of telecommunication services in 2001-2005, January 2006

[47] The Office of Electronic Communications (2007). State of the Market Report in 2006, UKE, Warsaw, April 2007, p. 95

[48] Worldscreen (2006); http://www.worldscreen.com/europe.php

[49] http://www.bip.uke.gov.pl/bipurtip/_gAllery/25/66/2566.pdf

[50] http://www.biznespolska.pl/files/reports/TPSA_191205.pdf

[51] http://www.internetworldstats.com/dsl.htm

[52] http://www.pcworld.pl/news/89293/100.html

[53] http://www.stat.gov.pl

[54] http://www.uke.gov.pl,

[55] http://www.worldscreen.com/europe.php

[56] http://www.epractice.eu

\section{Biographies}

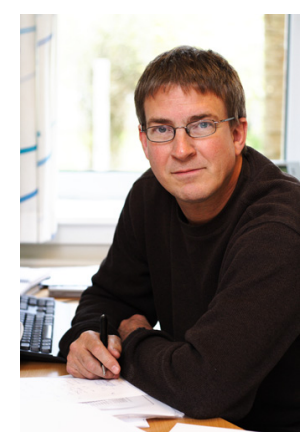

Anders Henten is Professor with special responsibilities at center for Communication, Media and Information technologies (CMI) at the Department of Electronic Systems at Aalborg University in Copenhagen. He is a graduate in communications and international development studies from Roskilde University in Denmark (1989) and holds a Ph.D. from the Technical University of Denmark (1995). He has worked professionally in the area of communications 
economy and policy for more than 25 years. He has participated in numerous research projects financed e.g. by the European Community, the Nordic Council of Ministers, Danish Research Councils and Ministries, and in consultancies, financed by World Bank, UNCTAD, ITU, Danish Ministries, etc. He has published nationally and internationally - more than 250 academic publications in international journals, books, conference proceedings, etc.

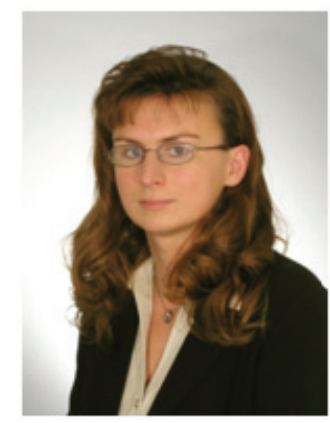

Iwona Maria Windekilde is Associate Professor at center for Communication Media and Information technologies (CMI), Aalborg University Copenhagen, Denmark. She completed her Ph.D. at Szczecin University in Poland in 2002. From the year 2002 to 2005 she worked as an Assistant Professor at Szczecin University in Poland at the Department of Economics and Organization of Telecommunication. During her work at the University she received a prize of the Headmaster of the Szczecin University for outstanding achievements on the field of didactics. In 2005 she received Marie Curie Intra-European Fellowships - project co-funded by the European Commission within the Sixth Framework Programme. During her work at CMI she was involved in several international projects and she has published number of publications within the areas of ICT, broadband development, business model for personal electronic networks, Green ICT, telecom networks, IT and broadcasting. 